$$
\begin{gathered}
\text { 中 耳 腺 腫 症 例 } \\
\text { 神戸市立中央市民病院耳鼻咽喉科 } \\
\text { 山本 悦 生, 広 野 喜 信, 大 村 正 樹, 磯 野 道 夫, 水上 千佳司 }
\end{gathered}
$$

\title{
REPORT OF A CASE WITH ADENOMA OF THE MIDDLE EAR
}

\author{
ETSUO YAMAMOTO, M.D., YOSINOBU HIRONO, M.D., MASAKI OHMURA, M.D., \\ MICHIO ISONO, M.D. and CHIKASHI MIZUKAMI, M.D.
}

Department of Otolaryngology, Kobe City General Hospital, Kobe

A 44-year-old female with adenoma of the middle ear was reported. Her chief complaint was hearing loss in the right ear. A white mass inside the right external auditory canal was observed. Audiometry revealed a combined deafness with the average hearing of $38.3 \mathrm{~dB}$ for the speech frequencies. The study by high resolution X-ray CT revealed a density area as like as a soft mass in the tympanic cavity.

A tumor existing mainly in the hypotympanum was surgically removed and modified type III tympanoplasty by interposing the malleus head as an autograft as a columella was done. Postoperative course was good and the average hearing improved slightly to $30 \mathrm{~dB}$. Histopathological study with stains of HE, PAS, mucicarmin, colloid iron, NSE and S-100 protein showed adenoma of the middle ear.

Key words : 中耳, 腺腫, 病理組織

A $93-2047-22204$

\section{1.はじめに}

中耳原発の腫湯は非常にまれであり, 腺腫の病理診 断は未確立な部分があり, 難しい. 最近, 全摘出後, 鼓室形成術を施行した中耳腺腫症例を経験し, 病理組 織学的検討を詳細に行ったので，報告する。

$$
\text { 2. 症例 }
$$

患者：44歳, 女性

主訴：右難聴

既往歴：鉄欠乏性貧血，胃潰瘍

家族歴：特記すべきことなし

現病歴：約 10 力月前に右難聴に気付き, 徐々に増悪 し，右の耳閉感および耳鳴（ピー，ピー）を伴うよう になり, 某医で外耳道腫瘍を指摘され，当科を受診し た.

初診時所見：右鼓膜の後上部より外耳道に突出し，

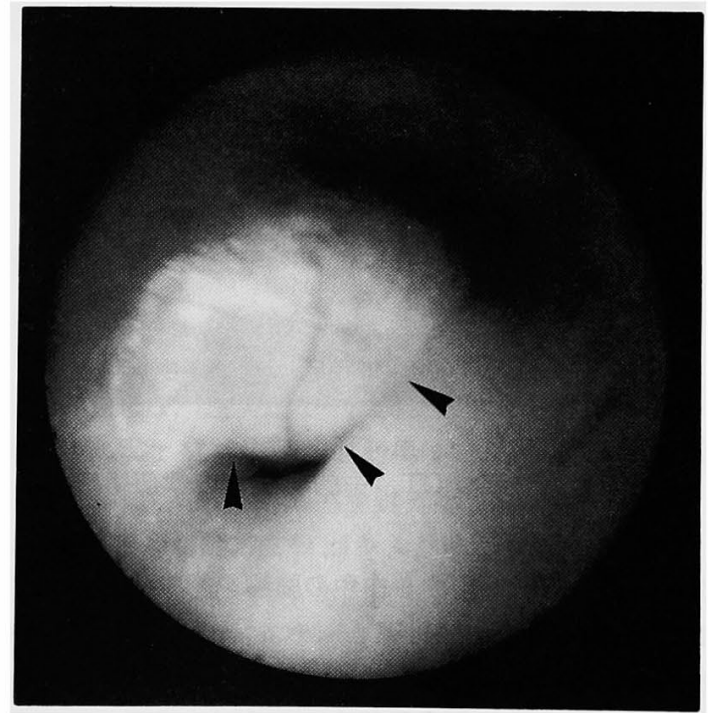

図 1 外耳道に突出した腫瘍（矢印） 


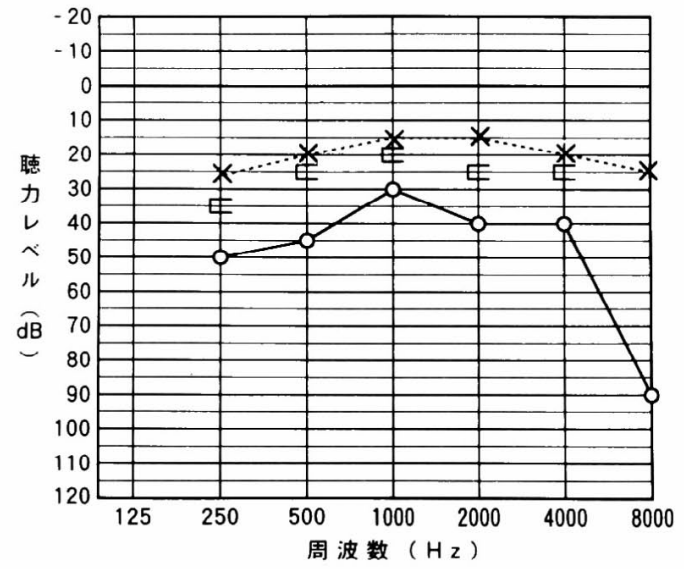

図 2 術前のオージオグラム

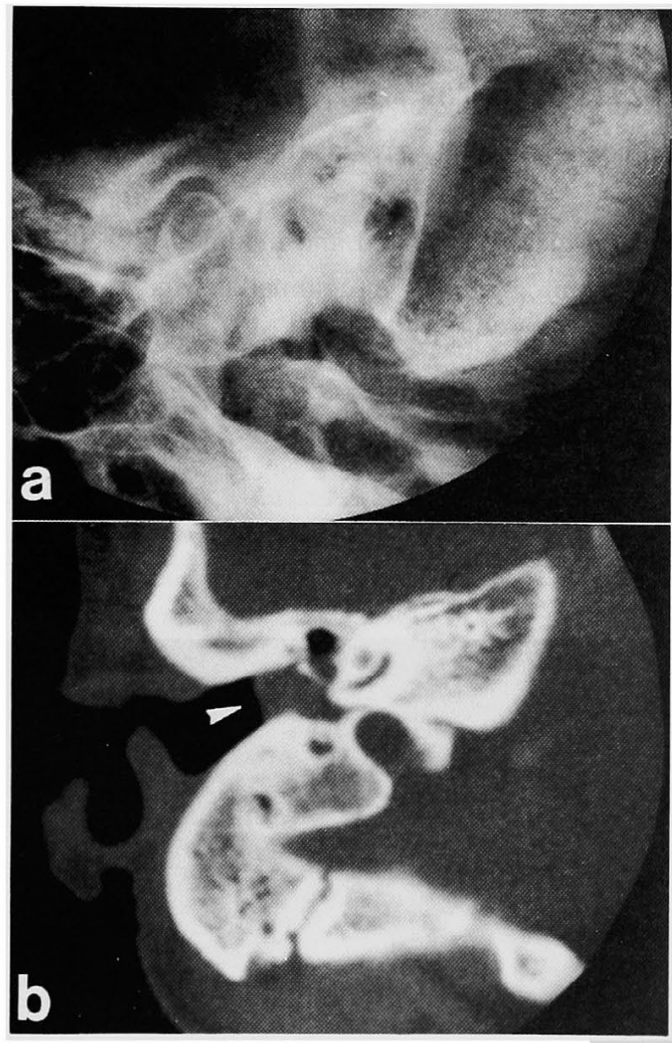

图 3 耳 $\mathrm{X}$ 線所見 ( $\mathrm{a}$ : 単純耳 $\mathrm{X}$ 線シュラー法, b : 側 頭骨高分解能 CT, 矢印は鼓室内軟部組織陰影 を示す)。

外耳道内をほぼ閉塞する白色の腫瘤を認め(図 1 )，右 耳は混合性難聴があり(図 2), ティンパノグラムは As 型であった。耳 X線検査では, 単純X線で右乳突蜂巣 の発育抑制があり(図 $3, \mathrm{a}$ ), 高分解能 CT で鼓室内

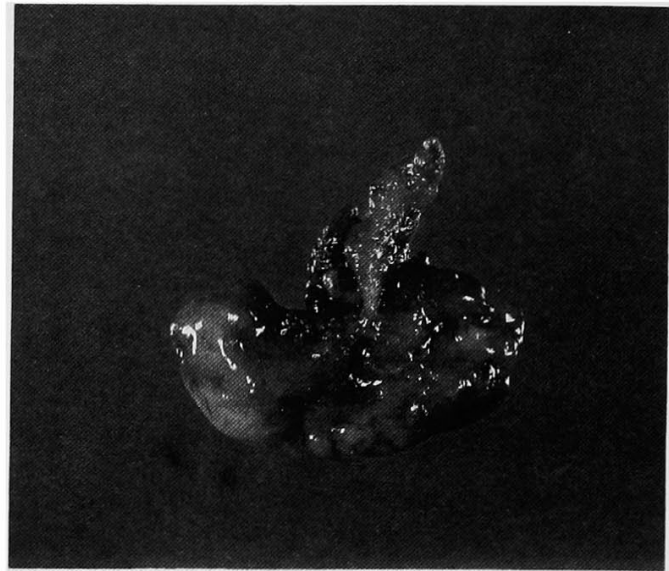

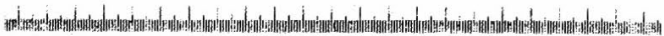

図 5 下鼓室に存在した腫瘍状塊

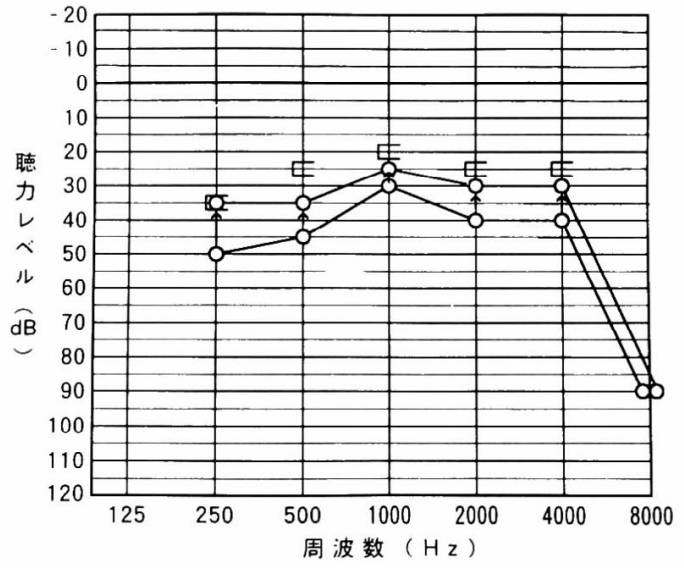

図 6 術後 7 カ月のオージオグラム

に充満する軟部組織陰影が認められた(図 3，b )。以 上より, 中耳の先天性真珠腫あるいは腫瘍性病変を疑 って，手術した。

手術および経過：局所麻酔で, 耳後部切開を行い, 鼓室, 乳突腔を開放した(図 4 )。非出血性の腫瘍状塊 が鼓室内に充満し, 外耳道に突出する型で存在したが, 鼓膜穿孔はなかった(a).耳小骨はこの中に埋没する

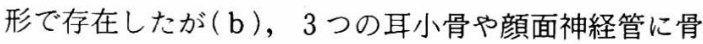
欠損はなかった。外耳道後壁は削除し，キヌ夕骨を摘 出し, ツチ骨頭を切除して, 中, 下鼓室を中心に存在 した腫湯状塊（c）は完全摘出した。先に切除した自 家ツチ骨頭をコルメラとしてIII型変法とし，鼓膜前部 は残せたので，側頭筋膜を underlay した（d）. 図 5 に摘出標本の一部を示す。術後経過は良好で，7 月月 

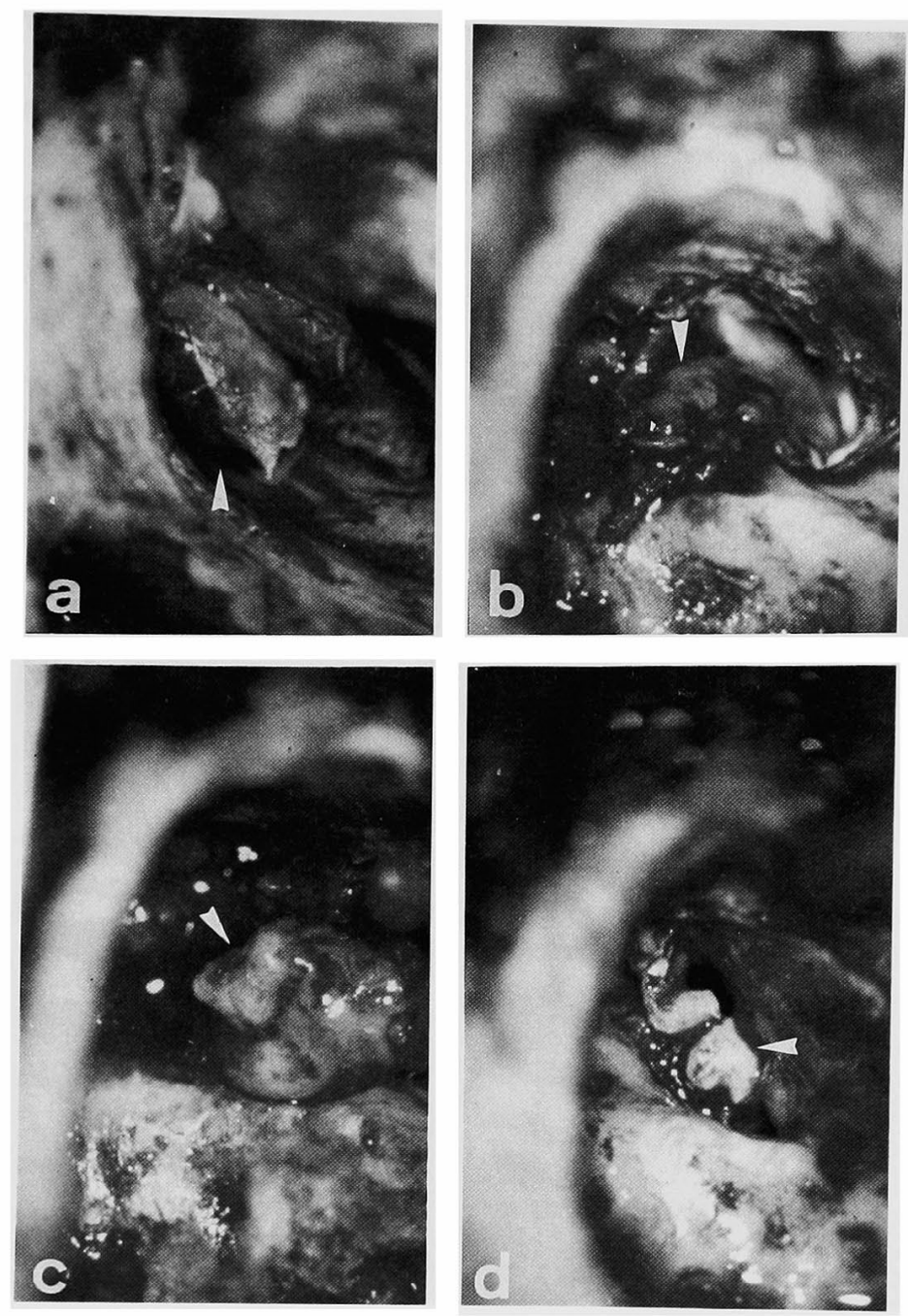

図 4 手術所見（矢印は, $\mathrm{a}$ ：外耳道に突出した腫瘍, b : 耳小骨周囲の肉芽, c : 下鼓室の腫湯, d : コ ルメラを示す)。

後の現在, 中耳内は乾燥しており, 会話音域の平均聴 力は $30 \mathrm{~dB}$ であり（図 6 ), 再発の徵候はない.

病理検査所見：HE 染色では，円柱状あるいは立方 状の腫慯細胞が, trabecular または sheet 状あるいは 腺腔を形成するように配列して増殖していた。さらに， 細胞の異型性は少なく, mitosisもほとんど認められ なかった(図 7, a). 腺腔内部には, PAS, ムチカル ミン,コロイド鉄染色で陽性に染まる粘液性の分泌物 が認められた(図 7，b，c，d).また NSE(neuron specific enolase) 染色, S-100蛋白染色ともに陰性で あった，以上ょり，本腫敀は中耳粘膜に発生した原発
性の腺腫と診断された。

\section{3. 考按}

中耳腺腫は，性差はなく，特に好発年齢もない。特 異な症状はなく, 無症状のこともあるが11 3), 徐々に進 行する難聴, 耳鳴, 耳閉感を訴えることが多( ${ }^{1 / 4)}$. 時 に，中耳炎を併発して耳漏をきたすことがある5．ま た, 顔面神経麻痺を伴った症例も報告されている ${ }^{1221}$.

中耳原発の腫县としては, 腺腫以外に傍神経節腫, 耳垢腺種, カルチノイド腫崵, 神経靽腫, 腺癌, 扁平 上皮癌などがあり, 臨床的には腺腫とこれらの腫瘍と 


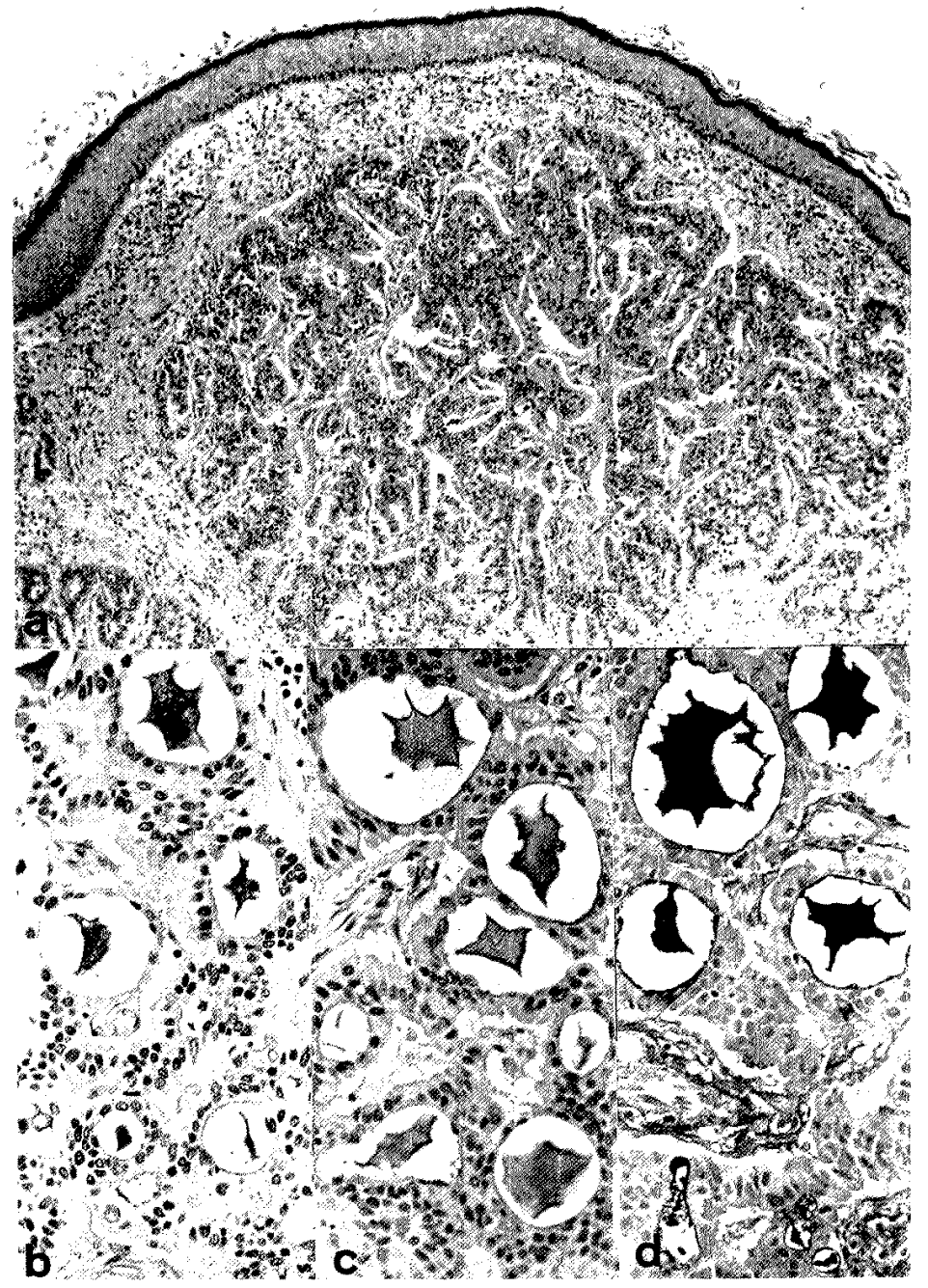

図 7 病理所見 $(\mathrm{a}: \mathrm{HE}$ 染色, b: PAS 染色, $\mathrm{c}$ ：么千 カルミン染色, d：コロイド鉄染色)

の鑑別が必要となる。病理組織学的には, HE 染色標本 で形態学的にきわめて類似しているカルチノイド腫怚 や傍神経節腫との鑑別が難しい，これらの腫湯では， 免疫組織学的染色である NSE, S-100 蛋白各染色が 陽性となり，電子顕微鏡的に membrane bound granuleが証明されるといわれているけー7゙. 本報告例では, HE 染色でカルチノイド腫瘍に類似した形態を示した が、細胞の異型性が少なく悪性腫湯は否定された。電 子顕微鏡による観察は行わなかったが, NSE 染色, S 一100蛋白染色ともに陰性であり，傍神経節腫，力ルチ ノイド腫湢は否定された。さらに, 腺腔様構造を有し, その内部门粘波性分泌物が，PAS，ム千カルミン、コ
ロイド鉄染色ともに陽性であり，腺腫と診断された。 中耳腺腫の発生起源は, 耳垢腺")や異所性唾液腺" とする報告もあるが, 最近, 電子顕微鏡的に腫瘍細胞 と中耳粘膜上皮との間に共通点があることが分かり， 中耳粘膜起源の腫助上考えるのが妥当上思われ $3^{46610)}$.

従来, 中耳源発の腺腫様腫演は ceruminal gland adenoma, salivary gland adenoma, adenocarcinoma, adenoid cystic carcinomaなどと診断されて いたが, Hyamsと Michaels (1976) ${ }^{6}$ が20例の中耳原 発の腺腫様腫廈の病理, 臨床像, 治療成績を検討して, 中耳腺腫の存在を指摘して，そのほとんよ゙は本腫劰で 
あるとした，その診断基準として，骨破壊がないこと， 腄場が中耳内に限局していること，隣接組織への浸潤 や転移がないことをあげた。本邦での中耳腺堙の報告 例は, 学会報告例の 2 例 ${ }^{1212)}$ のみであるが，上記の診 断基準に従い，詳細な病理検查を行っておれば，中耳 腺腫例と診断される症例はもっと多くあったと考元ら れる。

治療法として，本腫湯は良性あるいは悪性度の低い もので，限局性で転移はないので，局所の全摘出で再 発はまずない五，従って，摘出後は，本例のように積極 的に耳小骨形成を行うべきだと考える。

\section{4.まとめ}

病理組織学的検索を詳細に行い, 中耳腺腫と診断さ れた44歳女性例を報告した。

\section{参考文献}

1) Jahrsdoerfer RA, Fechner RE, Moon $\mathrm{CN} J r$ et al : Adenoma of the middle ear. Laryngoscope 93: 1041-1044, 1983.

2) Hagen WE, Leonard GL, Ichinose $\mathrm{H}$ et al : Primary monomorphic adenoma of the middle ear. Laryngoscope 90 : 1962-1972, 1980.

3) Pallanch JF, Weiland LH, Mc Donald TJ et al: Adenocarcinoma and adenoma of the middle ear. Laryngoscope 92: 47-54, 1982.

4) Riches WG, Johnston WH: Primary adenomatous neoplasms of the middle ear. Light and electron microscopic features of a group distinct from the ceruminomas. An J Clin Path 77: 153-161, 1982.
5) Stone H, Lipa M, Bell R : Primary adenocarcinoma of the middle ear. Arch Otolaryngol 101 : 702-705, 1975.

6) Hyams VJ, Michaels L: Benign adenomatous neoplasm (Adenoma) of the middle ear. Clin Otolaryngol 1:17-26, 1976.

7) Gillanders D, Worth A, Honore L: Ceruminous adenoma of the middle ear. Can J Otolaryngol 3: 194-201, 1974.

8) Harrison $K$, Cronin J, Greenwood N : Ceruminous adenocarcinoma in the middle ear. J Laryngol Otol 88: 363-368, 1974.

9) Caplinger CB, Hora JF: Middle ear choristoma with absent oval window. Arch Otolaryngol 85 : 365-366, 1967.

10) Kawabata I, Paparella MM : Ultrastructure of normal human middle ear mucosa. Ann Otol Rhinol Laryngol 78: 125-137, 1969.

11）池田昌毅, 調 重昭, 曾田豊二：カルチノイド腫湯が疑 わ机た中耳腺腫症例。䠦床耳科 $14: 293 ， 1987$.

12）渡辺悟郎, 黒田一, 福永昇, 网本途也, 小林一女: 中耳腺腫の1例。臨床耳科 $16: 126 ， 1989$.

本論文の要旨流, 第104回日耳鼻兵庫県地方部会 (平成元 年12月3日, 神戸) および，第91回日本耳型咽喉科学会総会 (平成 2 年 5 月17日, 東京) で発表した。

(1990年 7 月 27 日受稿 1990 年10月18日受理 急載)

別刷請求先 广650 神戸市中央区港島中町4-6 神戸市立中央市民病院耳鼻咽喉科 山本悦生 